\title{
Utilization of Mn-Doped ZnSe/ZnS Core/Shell Quantum Dots for Rapid Detection of Escherichia coli O157:H7 and Methicillin- Resistant Staphylococcus aureus
}

\author{
Thi-Diem Bui, ${ }^{1}$ Quang-Liem Nguyen, ${ }^{2}$ Thi-Bich Luong, ${ }^{2}$ Van Thuan Le $\mathbb{D},{ }^{3,4}$ \\ and Van-Dat Doan ${ }^{1}{ }^{1}$ \\ ${ }^{1}$ Faculty of Chemical Engineering, Industrial University of Ho Chi Minh City, Ho Chi Minh City 70000, Vietnam \\ ${ }^{2}$ Institute of Materials Science, Vietnam Academy of Science and Technology, 18 Hoang Quoc Viet, Hanoi 100000, Vietnam \\ ${ }^{3}$ Center for Advanced Chemistry, Institute of Research and Development, Duy Tan University, Da Nang 550000, Vietnam \\ ${ }^{4}$ The Faculty of Environmental and Chemical Engineering, Duy Tan University, Da Nang 550000, Vietnam
}

Correspondence should be addressed to Van-Dat Doan; doanvandat@iuh.edu.vn

Received 17 March 2020; Accepted 10 April 2020; Published 30 April 2020

Academic Editor: Zhiping Luo

Copyright $(92020$ Thi-Diem Bui et al. This is an open access article distributed under the Creative Commons Attribution License, which permits unrestricted use, distribution, and reproduction in any medium, provided the original work is properly cited.

In this study, Mn-doped ZnSe/ZnS core/shell quantum dots (CSQDs) were synthesized in aqueous solution using polyethylene glycol as a surface stabilizer and successfully applied in the detection of Escherichia coli O157:H7 and methicillin-resistant Staphylococcus aureus (MRSA) for the first time. The CSQDs were conjugated with anti-E. coli antibody and anti-MRSA antibody via protein $A$ supported by 1-ethyl-3-(-3-dimethylaminopropyl)carbodiimide hydrochloride for fluorescent labeling of the intact bacterial cells. The detection was performed for the bacterial strains cultivated in Luria-Bertani liquid medium. The obtained results indicate that E. coli O157:H7 and MRSA can be detected within $30 \mathrm{~min}$ at a high sensitivity of $10^{1} \mathrm{CFU} / \mathrm{mL}$. This labeling method based on the highly fluorescent CSQDs may have great potential for use in the food industry to check and prevent outbreaks of foodborne illness.

\section{Introduction}

Development of semiconductor nanocrystals or quantum dots (QDs) has been attracted great attention in the past decades due to their potential applications in molecular and cell imaging, biological probes, solar conversion components, optoelectronic components, and light-emitting devices [1-3]. Hitherto, Cd-based QDs (e.g., CdS, CdSe, and $\mathrm{CdTe}$ ) have been widely investigated due to their outstanding optical and electrical characteristics such as high photoluminescence quantum yield, broad absorption range, narrow and size-tunable emission, and photostability [4-7]. However, the inherent toxicity of cadmium has restricted the wide applicability of Cd-based QDs in biological applications. Therefore, many research groups have paid attention to develop Cd-free QDs for optoelectronics and biological applications [8-13]. Among Cd-free type II-VI semiconductors, $\mathrm{ZnSe}$ with a bandgap at room temperature of
$2.71 \mathrm{eV}$ [14] are considered as promising fluorescent materials due to their good optical characteristics, remarkable biocompatibility, and stability $[9,15,16]$. Recently, transition-metal-doped ZnSe semiconductors have been intensively developed to increase fluorescence efficiency of bare ZnSe [17-20]. The selection of transition-metal ions can be relied on their ion radius and bandgap energy. Among them, $\mathrm{Mn}^{2+}$ is commonly used as a doping agent for various types of semiconductor type II-VI thanks to the following: (i) the replaced positions by $\mathrm{Mn}^{2+}$ inside the lattice of the doped material can be examined by electron paramagnetic resonance; (ii) pure and strong dopant emission is observed due to $\mathrm{Mn}^{2+4} \mathrm{~T}_{1} \longrightarrow{ }^{6} \mathrm{~A}_{1}$ transition [21]. Besides, the bonds with $\mathrm{Mn}^{2+}$ on the surface of the nanocrystals have formed trapping states, affecting fluorescence and its quantum efficiency [22]. Therefore, as the passive surface states become stable, the QD's emission ability also becomes better $[23,24]$. 
One of the most well-known methods to stabilize the QDs surface is to wrap one or two layers of semiconductors with a larger bandgap $[24,25]$. Semiconductors selected to be sheathed should meet the following conditions: (i) the bandgap width of the shell must be greater than that of the core, so the confined carriers can be remained in the core of the nanocrystals; (ii) the lattice constant should be similar to that of the core so that the shell does not change too much at the junction between the two substances. Furthermore, a thick shell surrounding the nanocrystals will limit the trapped carriers on their surface, and adding a shell of semiconductors with a larger bandgap can increase the efficiency and improve their durability [23, 26, 27]. Compared to another popular II-VI material, ZnS with a large bandgap energy ranging from 3.56 to $3.76 \mathrm{eV}$ has outstanding photoelectric and luminescent properties with extensive applications [16]. Thus, the coating of a $\mathrm{ZnS}$ layer around Mndoped ZnSe QDs could improve its optical properties.

Escherichia coli (E. coli) O157:H7 and methicillin-resistant Staphylococcus aureus (S. aureus) (MRSA), two common pathogens, especially in food poisoning, are considered as a cause of infection of hospitals and communities because of the high possibility of causing death to patients and long-time treatment [28-31]. To detect these bacteria, the traditional culture methods are still used as a gold standard; however, it takes 3-5 days to get the desired results. Many methods of molecular biology such as polymerase chain reaction (PCR), including real-time PCR and pentaplex PCR, have been applied to quickly detect $E$. coli O157:H7 and MRSA [32-35]. However, false-negative results were still recorded in many cases due to several components contained in samples that can inhibit the PCR reaction when using this method for direct detection of bacteria. Fast and accurate detection methods of pathogens are an indispensable need in the current context, especially in developing countries, as the number of hospital infections and food poisoning is increasing day by day. The quick diagnosis will give a significant contribution to the right treatment, fast treatment map for improving patient's health. To solve the abovementioned problems, currently, the application of nanotechnology in biomedical research, namely, the rapid diagnosis of pathogenic microorganisms by nanotechnology is being intensively invested. In this context, the fluorescent labeling based on colloidal quantum dots has been increasingly developed due to many advantages over other methods, especially in the real-time study of biological processes [36-38]. Kloepfer et al. in 2003 initiated the use of QDs for bacterial labeling [39]. The nature of fluorescent labeling is of the possibility of conjugating the QDs to various types of biomolecules such as proteins and antibodies that are specifically coupled with respective antigens of bacteria. QDs have since been used for labeling and detection of numerous bacteria including Mycobacterium bovis, Bacillus Calmette-Guérin, E. coli O157:H7, Salmonella typhimurium, Bacillus anthracis, Staphylococcus aureus, Mycobacterium tuberculosis, and Listeria monocytogenes [40].

In our previous study, QDs of $\mathrm{ZnSe} / \mathrm{ZnS}: \mathrm{Mn} / \mathrm{ZnS}$ were successfully synthesized and applied in the detection of E. coli O157:H7 and MRSA using the fluorescent labeling method [41]. However, the synthesis process was quite complicated and the obtained suspensions of QDs were unstable over time, causing difficulties in practical applications. In this study, a fluorescent labeling for rapid detection of E. coli O157:H7 and MRSA by using more stable Mn-doped ZnSe/ZnS core/shell QDs (CSQDs) conjugated with antibody was provided. The water-dispersed $\mathrm{Mn}$ doped $\mathrm{ZnSe} / \mathrm{ZnS}$ CSQDs were prepared in the aqueous phase using polyethylene glycol (PEG) as a suitable surface stabilizer. The as-synthesized CSQDs were carefully characterized by means of X-ray powder diffraction (XRD), transmission electron microscopy (TEM), Fourier transform-infrared spectroscopy (FT-IR), UV-visible (UV-vis) spectrophotometry, and photoluminescence (PL) spectroscopy before being labeled with antibodies for the detection of E. coli O157:H7 and MRSA. Protein $A$ and 1ethyl-3-(-3-dimethylaminopropyl)carbodiimide hydrochloride (EDC) were used as crosslinkers to covalently conjugate antibodies onto the CSQDs surface. The compatibility of CSQDs with antibodies and the ability of the CSQD-labeled antibodies toward E. coli O157:H7 and MRSA bacteria were also evaluated. The structure of synthesized CSQDs and its application are illustrated in Scheme 1.

\section{Materials and Methods}

2.1. Materials. Zinc chloride $\left(\mathrm{ZnCl}_{2}, 99.9 \%\right)$, manganese(II) chloride $\left(\mathrm{MnCl}_{2}, 99.9 \%\right)$, sodium borohydride $\left(\mathrm{NaBH}_{4}\right.$, 99.9\%), selenium powder (Se, 99.9\%), zinc acetate dihydrate $\left(\mathrm{Zn}(\mathrm{OAc})_{2} \quad 2 \mathrm{H}_{2} \mathrm{O}, 99.9 \%\right)$, sodium sulfide nonahydrate $\left(\mathrm{Na}_{2} \mathrm{~S} .9 \mathrm{H}_{2} \mathrm{O}, 99.9 \%\right)$, sodium hydroxide $(\mathrm{NaOH}, 99.9 \%)$, polyethylene glycol-1500 (PEG-1500, 99.9\%), and 1-ethyl-3(-3-dimethylaminopropyl)carbodiimide hydrochloride (EDC, $\mathrm{C}_{8} \mathrm{H}_{17} \mathrm{~N}_{3}, 99.9 \%$ ) were purchased from Merck Co. Protein $A$ was supplied by Sigma Co. Antimethicillin-resistant $S$. aureus antibody [332/423] (ab62742) and anti-E. coli O157:H7 antibody (FITC) (ab31550) were purchased from ABcam Company. Two strains of E. coli O157:H7 and MRSA were provided by the Institute of Applied Materials Science, Vietnam Academy of Science and Technology, Ho Chi Minh City. The strains were stored at $-20^{\circ} \mathrm{C}$ in $20 \%$ glycerol until their use. Before use, the strains were cultured on Luria-Bertani (LB) medium at $37^{\circ} \mathrm{C}$ overnight, and the initial concentration of bacteria was determined by using the plate counting method. The bacterial strain cultures were then washed and diluted to a final concentration of $10^{6} \mathrm{CFU} / \mathrm{mL}$ by phosphate buffered saline (PBS), which was prepared by dissolving $8 \mathrm{~g}$ $\mathrm{NaCl}, 0.2 \mathrm{~g} \mathrm{KCl}$, and $1.44 \mathrm{~g} \mathrm{KH}_{2} \mathrm{PO}_{4}$ in $1 \mathrm{~L}$ distilled water and adjusted its $\mathrm{pH}$ to 7.4 .

2.2. Synthesis of Mn-Dopped ZnSe/ZnS CSQDs. The synthesis process can be divided into two stages as follows:

Stage 1. Synthesis of ZnSe:Mn as the core: zinc chloride $(0.1000 \mathrm{~g})$ and a calculated amount of manganese chloride were dissolved with $10 \mathrm{~mL}$ of $\mathrm{H}_{2} \mathrm{O}$ (solution 1). PEG $\left(0.05 \mathrm{~g}\right.$ ) was added to $80 \mathrm{~mL}$ of $\mathrm{H}_{2} \mathrm{O}$ and stirred for $15 \mathrm{~min}$ at $50^{\circ} \mathrm{C}$ (solution 2). Then, solutions 1 and 2 
were transfered to the three-neck flask and adjusted the $\mathrm{pH}$ to 7 by dilute $\mathrm{NH}_{4} \mathrm{OH} 0.01 \mathrm{M}$ solution. The reaction mixture was thoroughly stirred and degassed by inert gas of $\mathrm{N}_{2}$ during the reaction time and kept the reaction temperature at $80^{\circ} \mathrm{C}$ (solution 3). NaHSe solution was prepared from Se powder $(0.4 \mathrm{~g}), \mathrm{NaBH}_{4}(0.3 \mathrm{~g})$, and water in a vacuum jacketed reaction vessel. The asprepared NaHSe solution was then injected quickly into the abovementioned reaction solution 3 and kept continuously stirring at $80^{\circ} \mathrm{C}$ for $90 \mathrm{~min}$.

Stage 2. Shell coating process by $\mathrm{ZnS}$ for the core: $5 \mathrm{~mL}$ solution of $\mathrm{Zn}(\mathrm{OAc})_{2} .2 \mathrm{H}_{2} \mathrm{O}(0.05 \mathrm{~g})$ and $5 \mathrm{~mL}$ solution of $\mathrm{Na}_{2} \mathrm{~S} .9 \mathrm{H}_{2} \mathrm{O}(0.03 \mathrm{~g})$ were dropped down slowly one after another into the reaction vessel at stage 1 . The reaction mixture was then kept stirring for $90 \mathrm{~min}$ at $80^{\circ} \mathrm{C}$. Next, the mixture was cooled down and then aged at room temperature for 24 hours and stored for next experiments. The $\mathrm{ZnSe}: \mathrm{Mn} / \mathrm{ZnS}$ samples with a doped amount of $\mathrm{Mn}$ ranged from $1 \%$ to $11 \%$ were named as $\mathrm{ZnSe}: 1 \% \mathrm{Mn} / \mathrm{ZnS}$ to $\mathrm{ZnSe}: 11 \% \mathrm{Mn} / \mathrm{ZnS}$, respectively.

2.3. Characterization Methods. The crystal structure of Mndoped $\mathrm{ZnSe} / \mathrm{ZnS}$ CSQDs was analyzed by X-ray powder diffraction (XRD) using a D8 Advance-Bruker diffractometer with $\mathrm{CuK}_{\alpha}$ emission sources $(\lambda=1.5418 \AA)$. Photoluminescence (PL) intensity and the fluorescence performance were examined on a WGY-10 fluorospectrophotometer (Tianjin Gangdong Scientific and Technical Development CO., Ltd, PRC) using a Xe lamp as the excitation source. The PL measurements were recorded between 400 and $800 \mathrm{~nm}$ with an excitation wavelength of $350 \mathrm{~nm}$. The best excitation wavelength for fluorescence was determined via UV-Vis maximum absorbance on an Optizen 2120 UV spectrophotometer. Morphology and size of CSQDs were determined by transmission electron microscopy (TEM) on a JEM $2100 \mathrm{~F}$ with an acceleration voltage of $200 \mathrm{kV}$. The presence of functional groups in the product were determined by Fourier transform-infrared spectroscopy (FT-IR) using a FT-IR spectrometer (Brucker Equinox 55). Finally, the dynamic diameter of QDs in colloidal solution was examined by a Horiba SZ-100 nanoparticle analyzer (Japan) using dynamic light scattering (DLS) technology.

2.4. Preparation of CSQDs-Antibody Conjugates and Labeling. Conjugation of the anti-E. coli O157:H7 antibody and antiMRSA antibody to CSQDs were achieved by using protein $A$ and an EDC crosslinker. The method for conjugating proteins and antibody to QDs is described in detail in previous studies $[42,43]$. Typically, $30 \mu \mathrm{L}$ of the synthesized CSQDs suspension was mixed with $50 \mu \mathrm{L}$ of protein $A(2 \mathrm{mg} / \mathrm{mL})$ and $20 \mu \mathrm{L}$ of EDC $(20 \mathrm{mg} / \mathrm{mL})$ at a temperature of $4^{\circ} \mathrm{C}$ for 5 hours. Then, a calculated volume of anti-E. coli O157:H7 antibody $(5.5 \mathrm{mg} / \mathrm{mL})$ or anti-MRSA antibody $(1 \mathrm{mg} / \mathrm{mL})$ was added in the abovementioned mixture to obtain a suspension with antibody concentration of $5 \mu \mathrm{g} / \mathrm{mL}$. The obtained complex was shaken constantly at $4^{\circ} \mathrm{C}$ for 24 hours.
For the bacterial detection test, $20 \mu \mathrm{L}$ of the resulting CSQDs-antibody complex was added to $100 \mu \mathrm{L}$ of the bacteria suspensions with different concentrations in the range of $10^{1}-10^{6} \mathrm{CFU} / \mathrm{mL}$ and reacted at room temperature for the time interval from 5 to $30 \mathrm{~min}$. After the selected time period, the suspension containing CSQDs-antibody-bacteria was centrifuged at $5000 \mathrm{rpm}$ for $5 \mathrm{~min}$, washed twice with PBS buffer, and then dissolved again in $100 \mu \mathrm{L}$ of PBS. Finally, the studied samples were spread on glass slides and observed under a fluorescence microscope (Leica M205 FCA).

\section{Results and Discussion}

\subsection{Characterization of Materials}

3.1.1. Characterization of $\mathrm{ZnSe}: \mathrm{Mn}$ Cores. The $\mathrm{Mn}^{2+}$ content is an important factor affecting the optical properties of the prepared ZnSe:Mn QDs core. A series of ZnSe:Mn samples with the different concentrations of Mn were synthesized under the other experimental conditions fixed and then characterized to find the optimum Mn content in the QDs core. The light absorption of ZnSe:Mn solutions with different $\mathrm{Mn}$ concentrations was investigated by UV-Vis spectrophotometry. As shown in Figure 1(a), a small absorption peak at around $320 \mathrm{~nm}$ was assigned to the formation of an exciton of the intrinsic ZnSe nanocrystals. The negligible increase in intensity and the slight shift in the absorption spectra of ZnSe:Mn QDs as increasing the amount of $\mathrm{Mn}$ element revealed the formation of a bigger QDs particle size [44, 45].

The PL emission spectra of ZnSe:Mn samples at different Mn concentrations are presented in Figure 1(b). It can be seen that the PL emission spectra show the emission peaks at $595 \mathrm{~nm}$ corresponding to $\mathrm{Mn}^{2+4} \mathrm{~T}_{1^{-}}{ }^{6} \mathrm{~A}_{1}$ transition [21, 22]. At $1 \%$ doped $\mathrm{Mn}$ concentration, the characteristic orange luminescence intensity assigned to the $\mathrm{Mn}^{2+}$ center is weak. As the concentration of doped Mn increases, the luminescence intensity of the QDs nanoparticles increases and reaches optimum at $\mathrm{Mn}$ concentration of 5\%. However, the further increase in doped Mn concentration leads to a decrease in luminescence intensity. It could be explained by the fact that the higher the concentration of $\mathrm{Mn}$, the more the interaction between $\mathrm{Mn}-\mathrm{Mn}$, resulting in reducing fluorescent efficiency. At $11 \% \mathrm{Mn}$ concentration, the obtained fluorescent light has a faint orange color. Thus, doped Mn concentration dramatically affects the luminescence intensity and luminescent color of quantum dots. The XRD patterns of ZnSe:Mn samples presented in Figure 1(c) show three broad diffraction peaks at $27.21^{\circ}, 45.57^{\circ}$, and $53.27^{\circ}$ corresponding to the planes (111), (220), and (311) of the cubic zinc blende of ZnSe nanocrystals [38, 42]. In addition, the small shift of the diffraction peaks of the $\mathrm{ZnSe}: \mathrm{Mn}$ to larger angles compared to the bare ZnSe (ICDD PDF no. 01071-5977) caused by the incorporation of $\mathrm{Mn}^{2+}$ ions into the $\mathrm{ZnSe}$ nanocrystal lattice was observed. The doping $\mathrm{Mn}^{2+}$ ions into the host $\mathrm{ZnSe}$ did not totally cause a crystal phase transformation. However, there were several small sharp peaks appeared in the XRD patterns of ZnSe samples with 


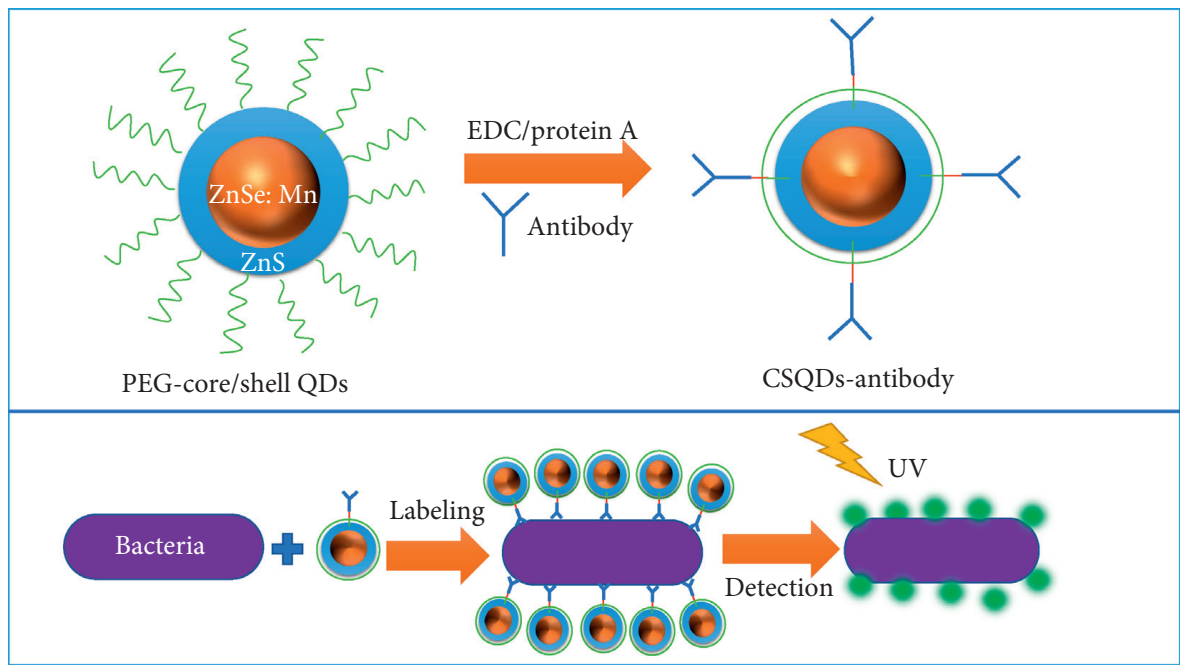

Scheme 1: Schematic representation of the CSQDs-antibody structure and the bacteria detection.
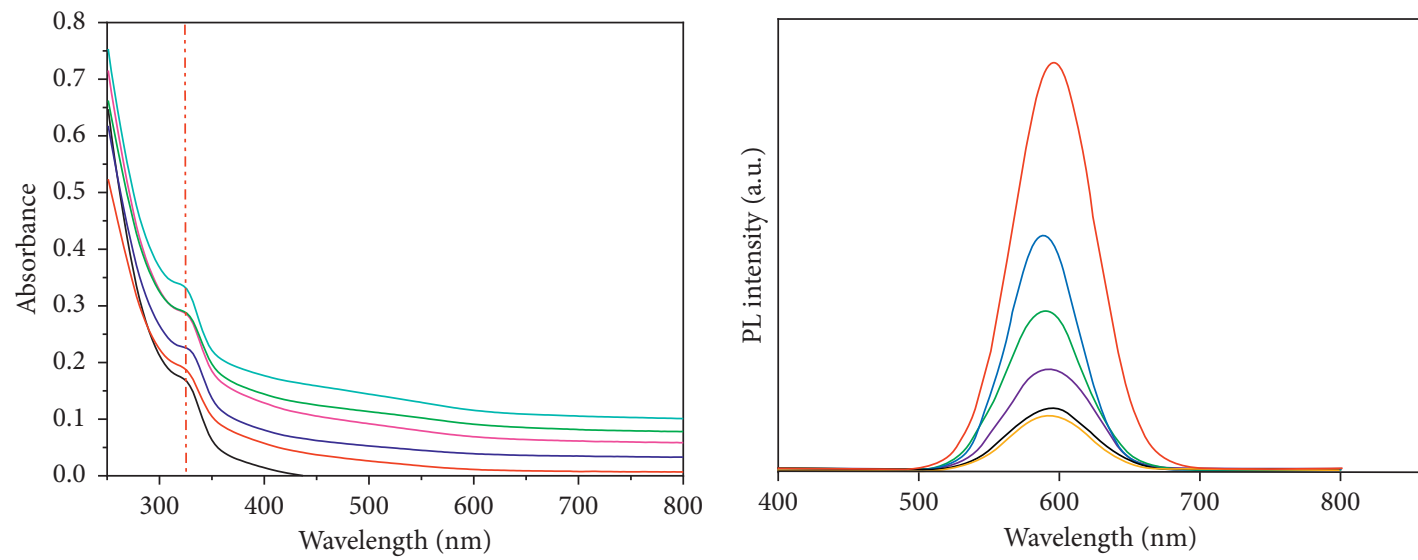

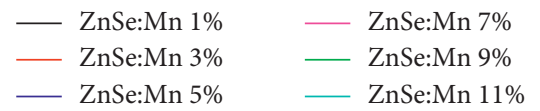

(a)

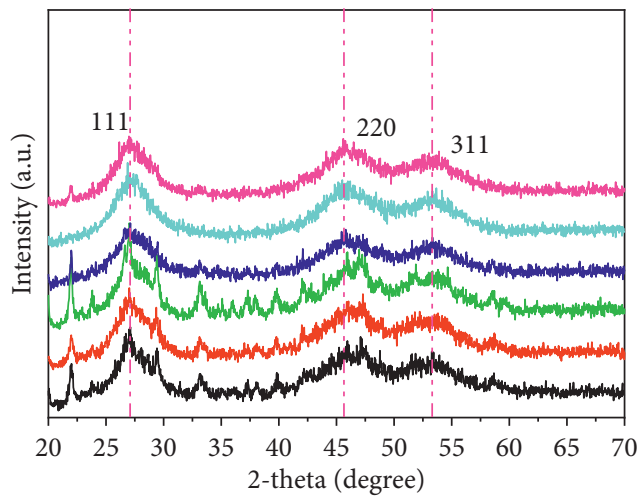

$\begin{array}{ll}\text { - ZnSe:Mn 1\% } & - \text { ZnSe:Mn 7\% } \\ \text { ZnSe:Mn 3\% } & - \text { ZnSe:Mn 9\% } \\ \text { Z ZnSe:Mn 5\% } & - \text { ZnSe:Mn 11\% }\end{array}$

(c)

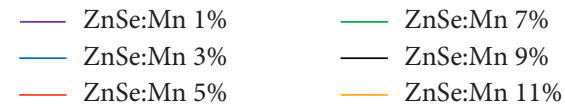

(b)

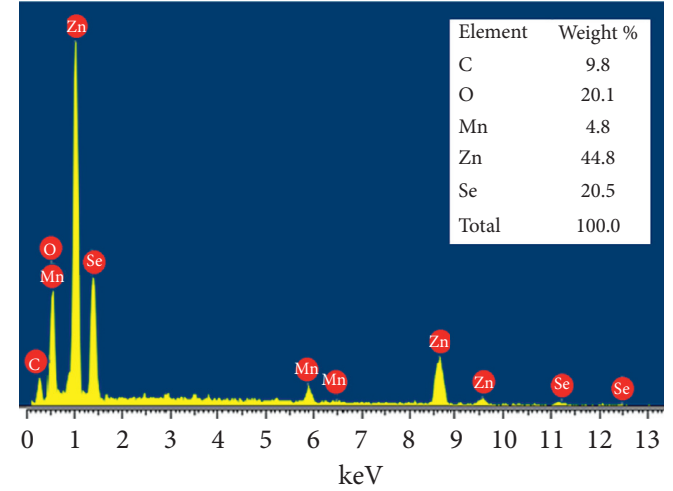

(d)

FIgURE 1: UV-Vis absorption spectra (a). PL emission spectra (excitation wavelength of $350 \mathrm{~nm}$ ) (b). XRD patterns (c) of the ZnSe:Mn core with different Mn concentrations, and the EDX spectrum of the ZnSe:5\% Mn sample (d). 


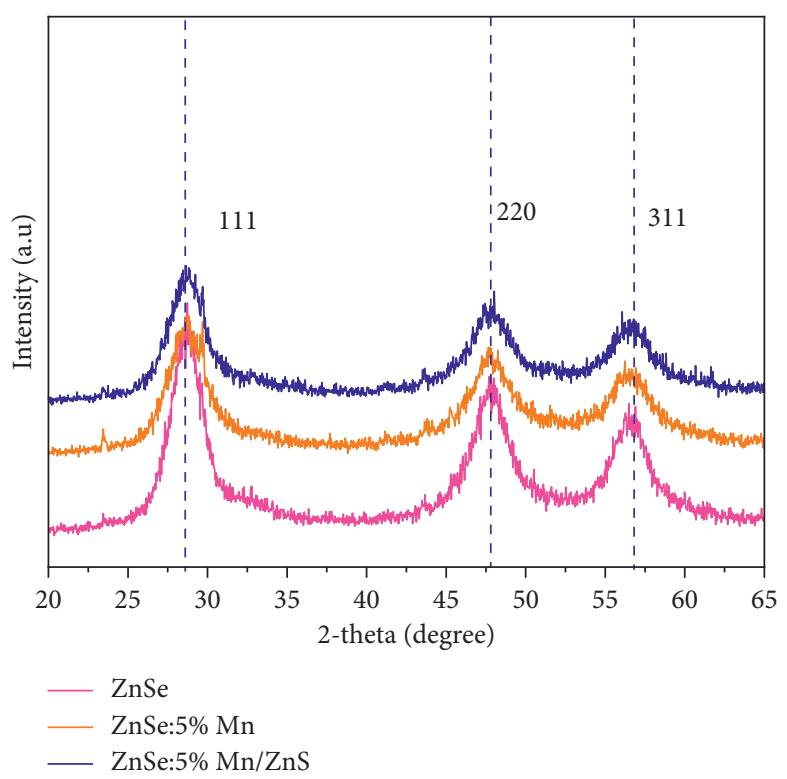

(a)
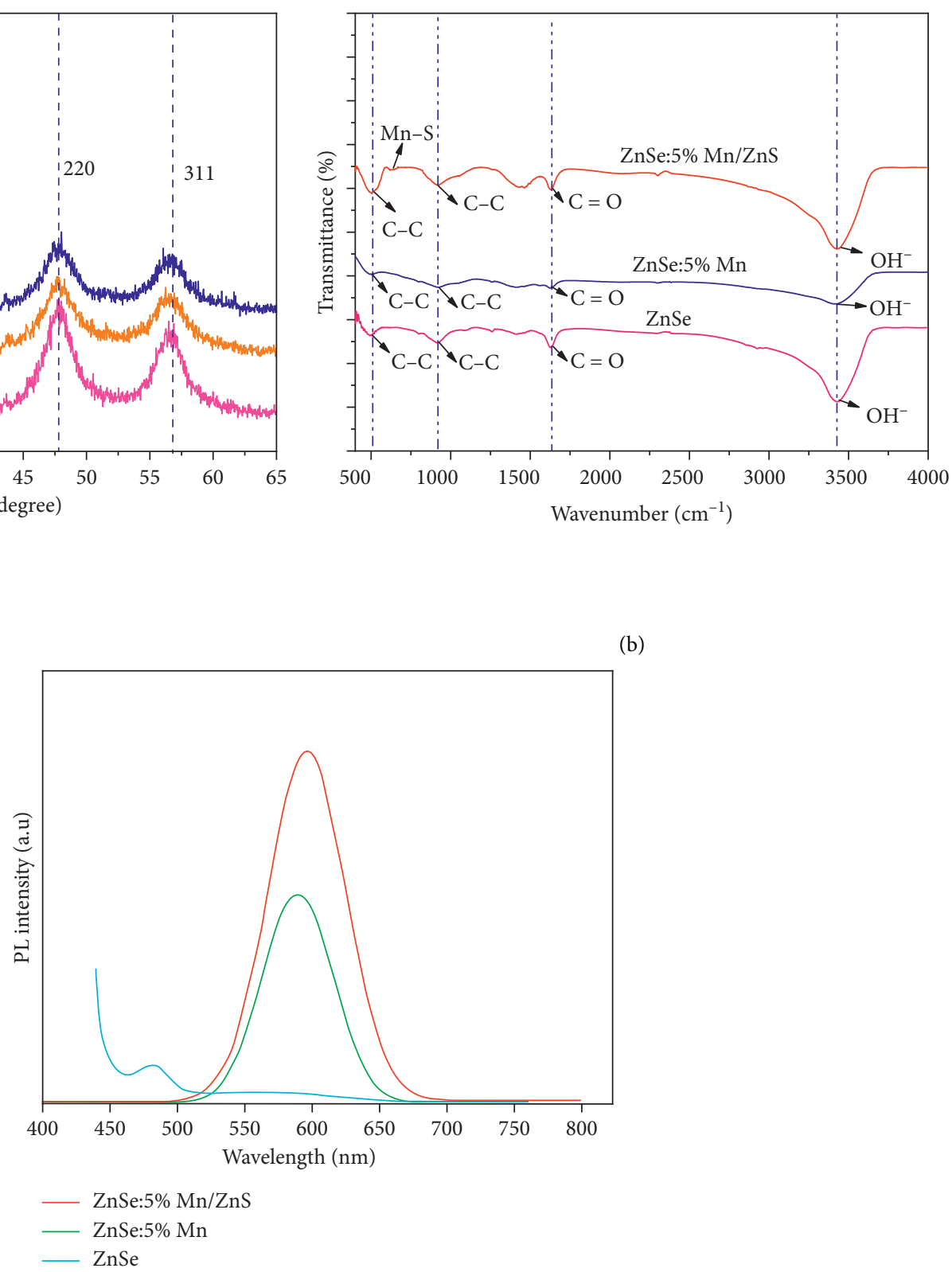

(b)

(c)

Figure 2: XRD patterns of ZnSe:Mn/ZnS with different Mn concentrations (a). FTIR spectra (b) and PL emission spectra (with 315 mn excitation) of $\mathrm{ZnSe}, \mathrm{ZnSe}: 5 \% \mathrm{Mn}$, and $\mathrm{ZnSe}: 5 \% \mathrm{Mn} / \mathrm{ZnS}$ (c).

low concentrations of doped Mn. It could be explained by the formation of two crystalline phases of the zinc blende and hetaerolite, therein hetaerolite played a role of secondary phase [27]. It is noted that the sample with a $5 \% \mathrm{Mn}$ possesses the highest PL intensity; therefore, the concentration of $5 \%$ doped Mn QDs was chosen as a premise for next steps of the synthesis. The EDX spectrum of ZnSe:5\% Mn (Figure 1(d)) indicates that the main components of the synthesized ZnSe:Mn sample are $\mathrm{Zn}$ and Se elements with 44.8 and $20.5 \%$, respectively. The existence of Mn element in the product has also been found to be about $4.8 \%$, indicating that $\mathrm{Mn}$ successfully integrated into $\mathrm{ZnSe}$ structure. In addition, the EDX peaks of $\mathrm{C}$ and $\mathrm{O}$ elements also appeared, confirming that the PEG stabilizer was attached to the surface of luminescent QDs.

3.1.2. Characterization of $\mathrm{ZnSe:Mn/ZnS} \mathrm{CSQDs.} \mathrm{Figure} \mathrm{2(a)}$ shows the XRD patterns of $\mathrm{ZnSe}, \mathrm{ZnSe}: 5 \%$ Mn cores, and $\mathrm{ZnSe}: 5 \% \mathrm{Mn} / \mathrm{ZnS}$ CSQDs. It can be seen that the XRD patterns of the three samples are similar and have the diffraction peaks at around $27.31^{\circ}, 45.57^{\circ}$, and $53.27^{\circ}$, which are indexed as the cubic zinc blende structure as mentioned above. The XRD peaks of $\mathrm{ZnSe}: 5 \% \mathrm{Mn} / \mathrm{ZnS}$ CSQDs tend to be broadened and shift toward a larger angle in comparison to that of the $\mathrm{ZnSe}: 5 \% \mathrm{Mn}$ cores. This may be due of the size 


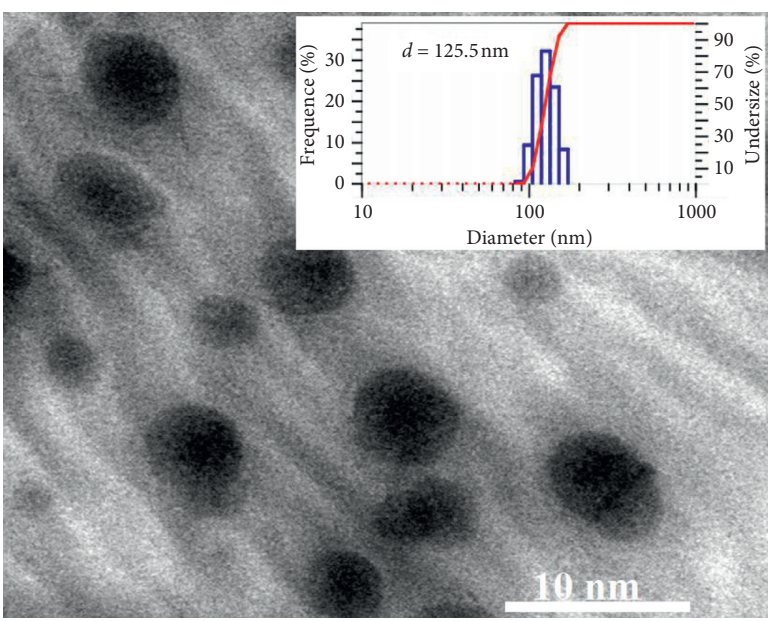

(a)

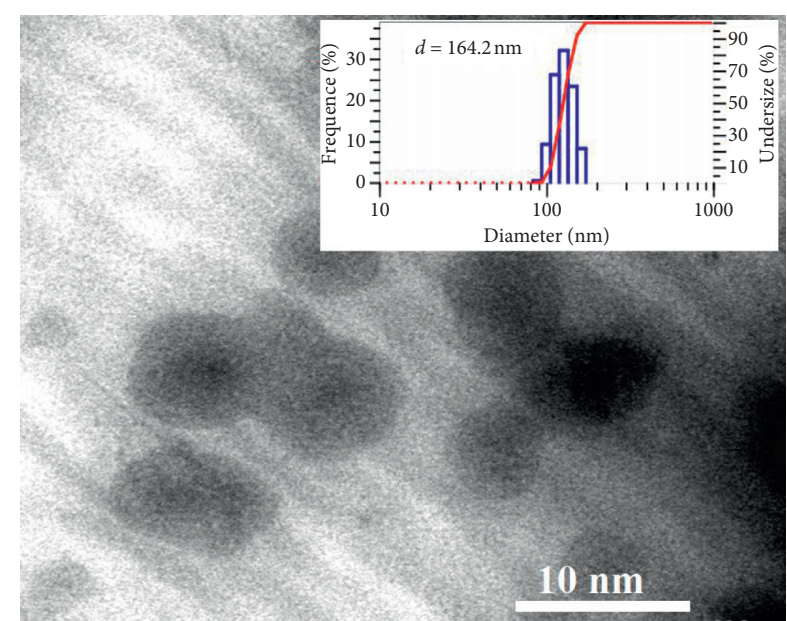

(b)

FIgURE 3: TEM images and DLS diagrams (insets) of ZnSe:5\% Mn (a) and ZnSe:\% 5 Mn/ZnS CSQDs (b).

effect caused by the $\mathrm{ZnS}$ shell surrounding the $\mathrm{ZnSe}: \mathrm{Mn}$ core QDs. The similar results have been published in many previous studies [46, 47].

The FTIR spectra of the ZnSe, ZnSe:5\% Mn, and ZnSe: $5 \% \mathrm{Mn} / \mathrm{ZnS}$ QDs stabilized by PEG are given in Figure 2(b). The bands at 3422 (broad), 1600, 1452, 890, and $504 \mathrm{~cm}^{-1}$ are assignable to stretching frequencies for $\mathrm{O}-\mathrm{H}, \mathrm{C}=\mathrm{O}, \mathrm{C}-\mathrm{H}$, and $\mathrm{C}-\mathrm{C}$, respectively. These functional groups demonstrated the existence of PEG on the surface of QDs, which is responsible for the good dispersion of QDs in water and makes them more compatible with bacterial cells. The band at $673 \mathrm{~cm}^{-1}$ appeared only on the $\mathrm{ZnSe}: 5 \% \mathrm{Mn} / \mathrm{ZnS}$ FTIR spectrum is attributed to the $\mathrm{Mn}$-S-specific vibrations, confirming a partial replacement of $\mathrm{Zn}^{2+}$ by $\mathrm{Mn}^{2+}$ ions [48].

Figure 2(c) shows comparison of PL spectra of the bare $\mathrm{ZnSe}, \mathrm{ZnSe}: 5 \% \mathrm{Mn}$, and $\mathrm{ZnSe}: 5 \% \mathrm{Mn} / \mathrm{ZnS}$ samples. From Figure 2(c), it can be seen that the ZnSe sample exhibited the very weak PL intensity with maximum at around $485 \mathrm{~nm}$, while the $\mathrm{ZnSe}: 5 \% \mathrm{Mn} / \mathrm{ZnS}$ CSQDs demonstrated increased $\mathrm{PL}$ intensity as compared to the $\mathrm{ZnSe}: 5 \% \mathrm{Mn}$ cores and bare $\mathrm{ZnSe}$, indicating the positive role of $\mathrm{ZnS}$ in increasing $\mathrm{PL}$ intensity for the CSQDs. The enhancement in PL intensity of the CSQDs, as explained in the previous reports $[46,49]$, is due to the significant reduction in the number of defects in the $\mathrm{ZnSe}: 5 \% \mathrm{Mn}$ core surface by the growth of an additional $\mathrm{ZnS}$ shell on the cores. Besides, the $\mathrm{ZnS}$ shell coating also led to a shift of the PL peak at $595 \mathrm{~nm}$ for the $\mathrm{ZnSe}: 5 \%$ Mn cores to the wavelength of about $605 \mathrm{~nm}$.

The TEM images of the ZnSe:5\% Mn core and ZnSe:5\% $\mathrm{Mn} / \mathrm{ZnS}$ core/shell with its dynamic particle size distribution are presented in Figure 3. The synthesized $\mathrm{ZnSe}: 5 \% \mathrm{Mn}$ cores appear as spherical particles and their average diameter is $7 \mathrm{~nm}$. The average diameter of $\mathrm{ZnSe}: 5 \% \mathrm{Mn} / \mathrm{ZnS}$ CSQDs is about $8.5 \mathrm{~nm}$, which is larger than that of the cores, indicating the formation of $\mathrm{ZnS}$ shell on the $\mathrm{ZnSe}: \mathrm{Mn}$ cores. As shown in the insets of Figure 3, the QDs have uniform dynamic particle size distribution, and this confirmed that the PEG surfactant played a perfect role in helping the particles disperse better in the suspension. The uniformity of $\mathrm{ZnSe}: 5 \% \mathrm{Mn} / \mathrm{ZnS}$ CSQDs is also consistent with the particle size distribution diagram through its narrow bottom width. It has been also found that the ZnSe:Mn cores and $\mathrm{ZnSe}: 5 \%$ $\mathrm{Mn} / \mathrm{ZnS}$ CSQDs have an average dynamic particle size of $125.5 \mathrm{~nm}$ and $164.2 \mathrm{~nm}$, respectively. The significant difference in dynamic particle size and the size recorded by TEM images is related to the PEG layer acting as an effective stabilizer for QDs.

\section{Application of CSQDs for Bacteria Detection}

The ability of CSQDs labeled with E. coli O157:H7 and MRSA was examined with different bacteria concentrations $\left(10^{1}, 10^{2}, 10^{4}\right.$, and $\left.10^{6} \mathrm{CFU} / \mathrm{mL}\right)$ at the reaction time ranging from 5 to $30 \mathrm{~min}$. It was observed that the clear fluorescence signals began to be recorded for all studied concentrations after $15 \mathrm{~min}$. The highest fluorescence signals in the detection of E. coli O157:H7 (Figure 4(a)) and MRSA (Figure 4(b)) with the lowest concentration of $10^{1} \mathrm{CFU} / \mathrm{mL}$ were obtained after 30 minutes of exposure. Besides, the achieved labeling efficiency of $E$. coli O157:H7 and MRSA with CSQDs was found to be high, approximately $100 \%$.

Figure 5 shows TEM images of E. coli O157:H7 and MRSA with and without CSQDs. It can be seen that the morphology of E. coli O157:H7 (Figure 5(a)) and MRSA (Figure 5(b)) is clearly visible due to the presence of CSQDs. It is well known that biological samples as well as bacteria belong to a class of nonconductive materials; therefore, it is difficult to show its images on an electron microscope. Here, the synthesized CSQDs can act as a conductive sputter coating, which improved the quality of TEM images of bacterial cells. Without CSQDs, E. coli O157:H7 and MRSA were almost impossible to detect by TEM (Figures 5(c) and $5(d))$. Interestingly, no evidence for rupture and collapse of bacterial cells was observed in the TEM images of E. coli O157:H7 and MRSA conjugated with CSQDs, demonstrating that the CSQDs do not exhibit cytotoxicity against 


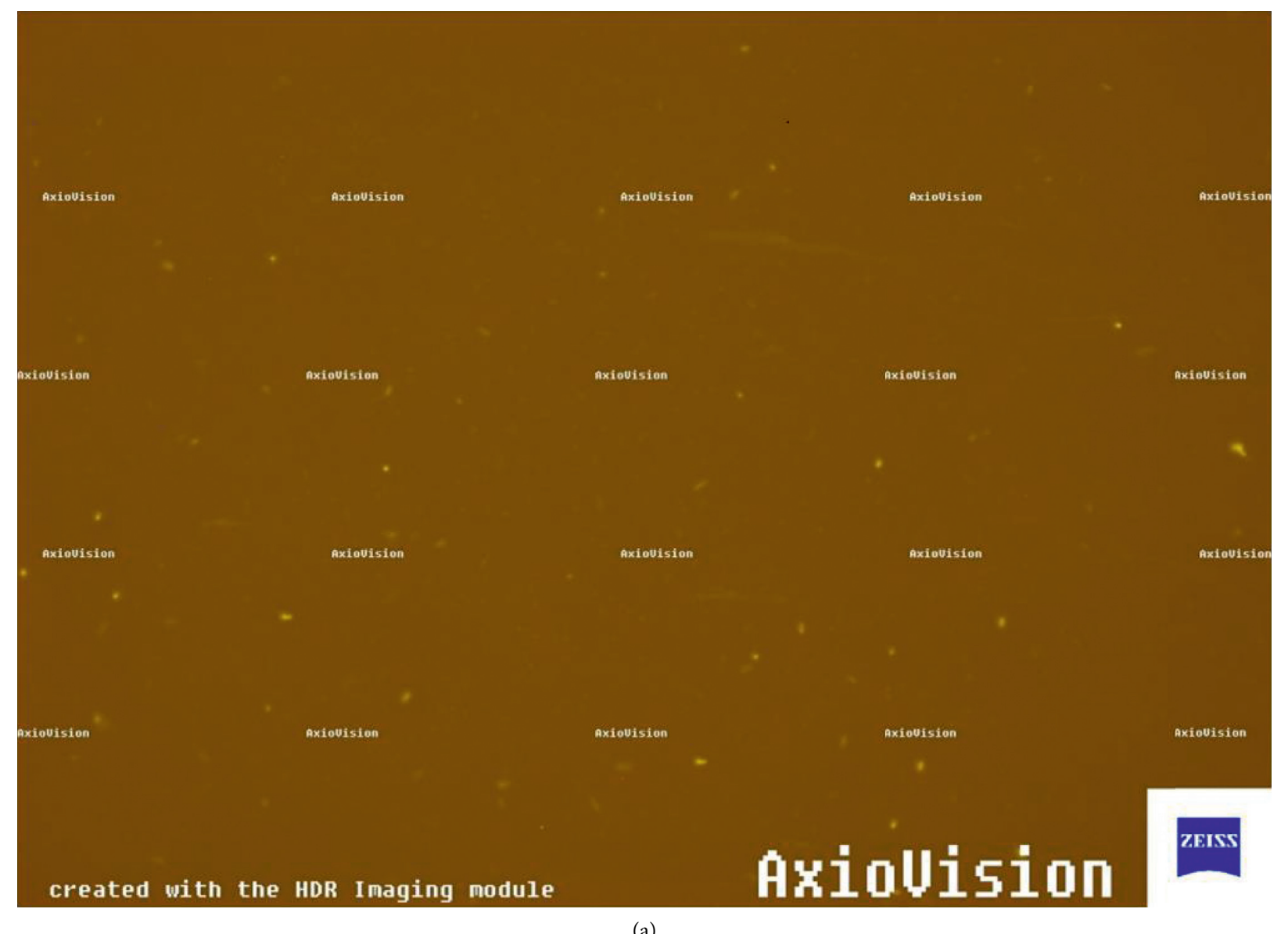

(a)

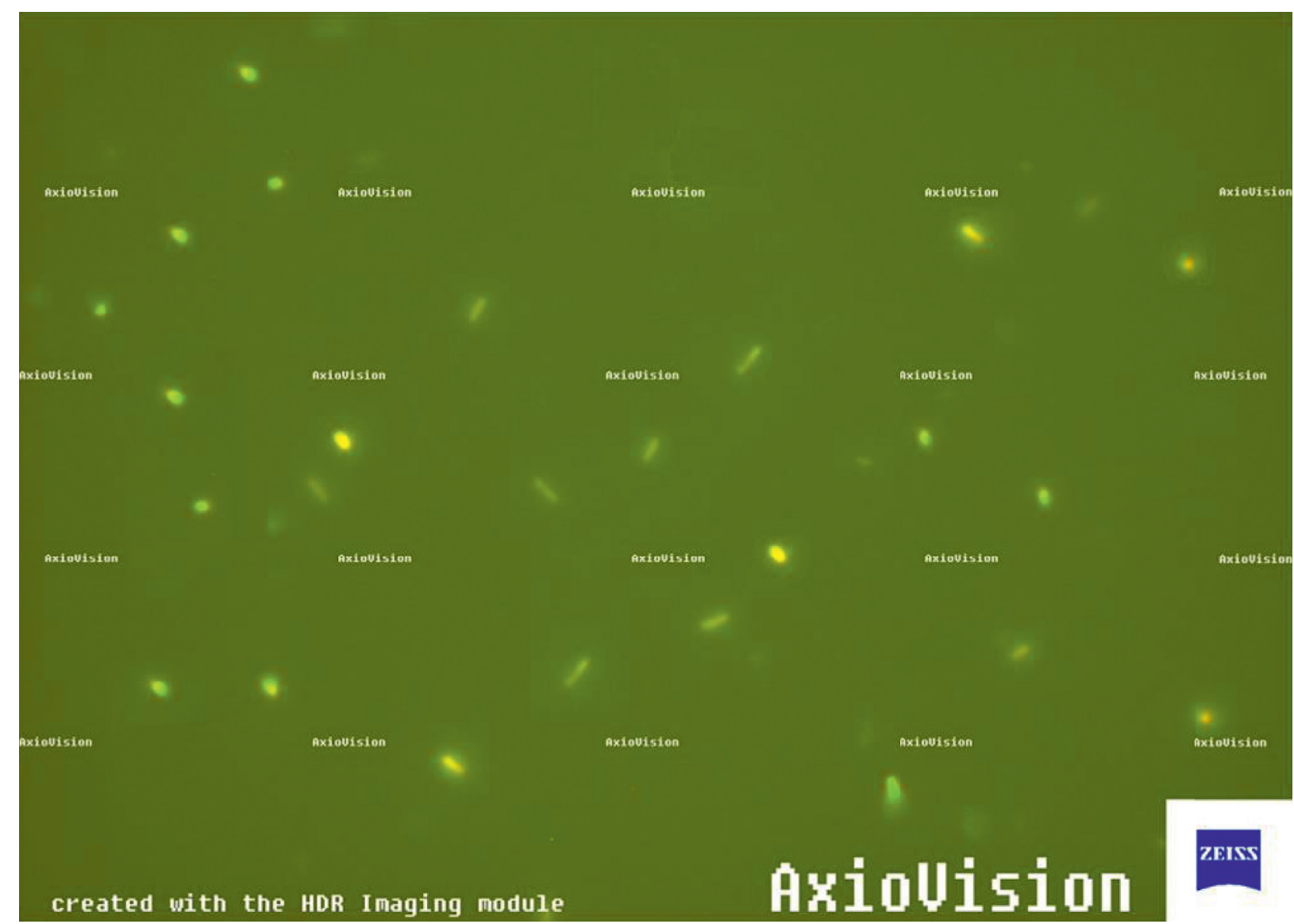

(b)

FIGURE 4: Fluorescent image of CSQDS-antibody-E. coli O157:H7 (a) and CSQDS-antibody-MRSA (b). 


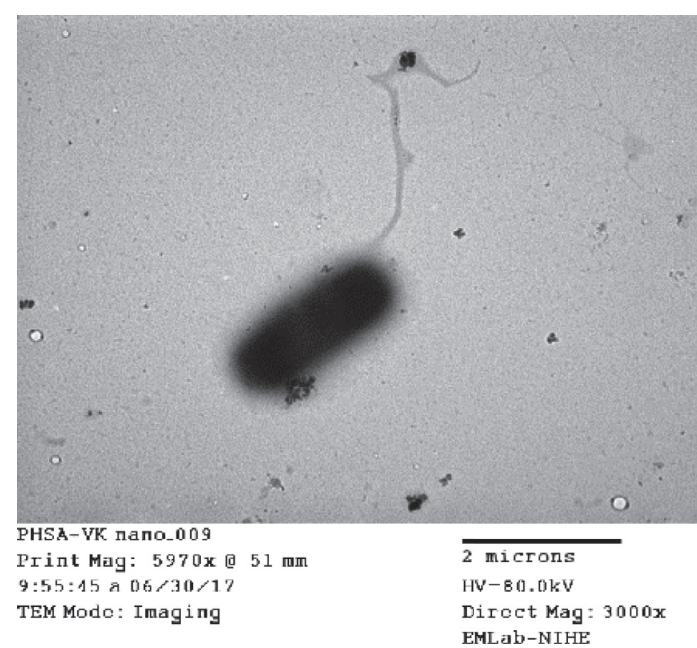

(a)

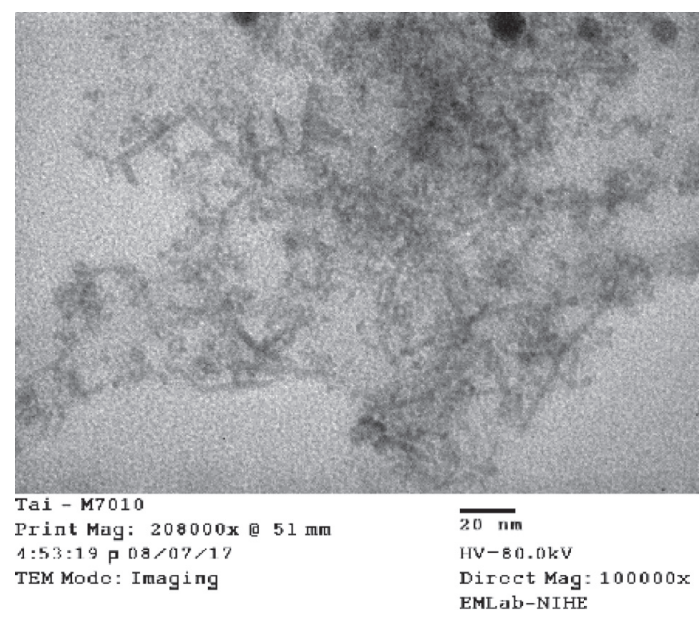

(c)

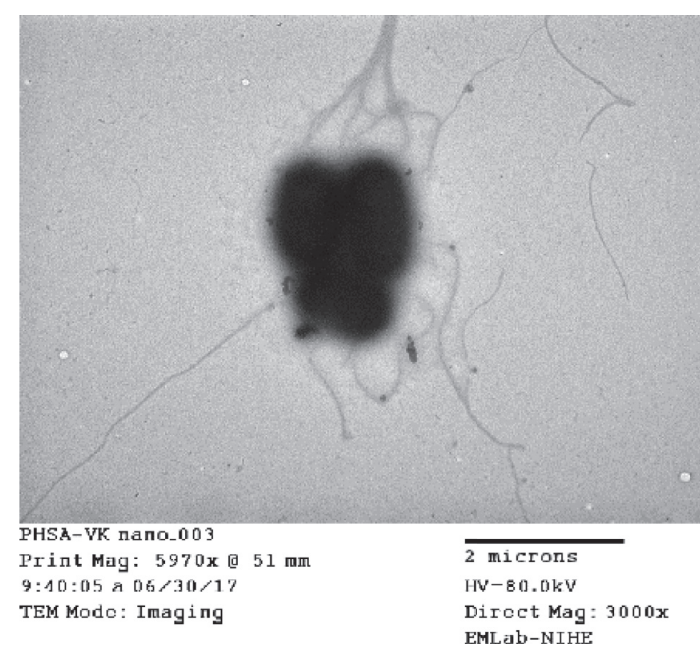

(b)

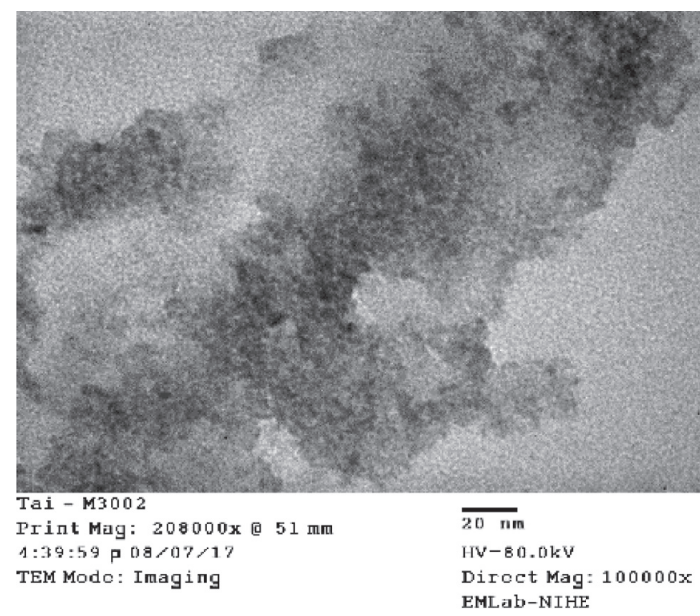

(d)

FIgure 5: TEM images of E. coli and MRSA with CSQDs (a, b) and without CSQDs (c, d).

the aforementioned strains at used concentration. Therefore, the synthesized CSQDs are eligible to be applied as an effective fluorescent labeling material.

\section{Conclusions}

In summary, Mn-doped $\mathrm{ZnSe} / \mathrm{ZnS}$ core/shell quantum dots were successfully synthesized and used for selective fluorescent labeling and detection of E. coli O157:H7 and MRSA. The synthesized CSQDs had an average particle diameter of $8.5 \mathrm{~nm}$ and exhibited high luminescence. The CSQDs conjugated well with the anti-E. coli O157:H7 antibody and anti-MRSA antibody via protein $A$ and EDC crosslinkers. The CSQDs-antibody complex allowed intensive detection of the bacteria at levels down to $10^{1} \mathrm{CFU} / \mathrm{mL}$ within $30 \mathrm{~min}$. The labeling efficiency of E. coli O157:H7 and MRSA with CSQDs-antibody complex was approximately $100 \%$. Thus, the provided CSQDs-antibody complex can be used as an effective and useful tool for detection of pathogenic bacteria by the fluorescence method in the clinical microbiology and biomedicine field as well as in dairy products to ensure the food safety.

\section{Data Availability}

The data used to support the findings of this study are included within the article.

\section{Conflicts of Interest}

The authors declare that they have no conflicts of interests.

\section{Acknowledgments}

The authors acknowledge the Industrial University of Ho Chi Minh City, Vietnam, for supporting this work (funding no. 184.HH01). The authors also would like to thank the Department of Science and Technology of Ho Chi Minh City for their support to complete this work.

\section{References}

[1] I. B. Bwatanglang, F. Mohammad, N. A. Yusof et al., "Histological analysis of anti-cancer drug loaded, targeted $\mathrm{Mn}: \mathrm{ZnS}$ quantum dots in metastatic lesions of $4 \mathrm{~T} 1$ challenged mice," 
Journal of Materials Science: Materials in Medicine, vol. 28, pp. 28-138, 2017.

[2] A. Manikandan, Y.-Z. Chen, C.-C. Shen, C.-W. Sher, H.-C. Kuo, and Y.-L. Chueh, "A critical review on two-dimensional quantum dots (2D QDs): from synthesis toward applications in energy and optoelectronics," Progress in Quantum Electronics, vol. 68, Article ID 100226, 2019.

[3] J. Ning, J. Liu, Y. Levi-Kalisman, A. I. Frenkel, and U. Banin, "Controlling anisotropic growth of colloidal ZnSe nanostructures," Journal of the American Chemical Society, vol. 140, no. 44, pp. 14627-14637, 2018.

[4] Z. Ahmad, M. A. Najeeb, R. A. Shakoor, S. A. Al-Muhtaseb, and F. Touati, "Limits and possible solutions in quantum dot organic solar cells," Renewable and Sustainable Energy Reviews, vol. 82, pp. 1551-1564, 2018.

[5] T. Hu, Z. Li, L. Lu et al., "Inorganic-organic CdSe-diethylenetriamine nanobelts for enhanced visible photocatalytic hydrogen evolution," Journal of Colloid and Interface Science, vol. 555, pp. 166-173, 2019.

[6] R. K. Ratnesh and M. S. Mehata, "Synthesis and optical properties of core-multi-shell CdSe/CdS/ZnS quantum dots: surface modifications," Optical Materials, vol. 64, pp. 250256, 2017.

[7] A. K. Visheratina, F. Purcell-Milton, R. Serrano-García et al., "Chiral recognition of optically active $\mathrm{CoFe}_{2} \mathrm{O}_{4}$ magnetic nanoparticles by $\mathrm{CdSe} / \mathrm{CdS}$ quantum dots stabilised with chiral ligands," Journal of Materials Chemistry C, vol. 5, no. 7, pp. 1692-1698, 2017.

[8] E. Soheyli, R. Sahraei, G. Nabiyouni, F. Nazari, R. Tabaraki, and B. Ghaemi, "Luminescent, low-toxic and stable gradientalloyed Fe:ZnSe(S)@ZnSe(S) core:shell quantum dots as a sensitive fluorescent sensor for lead ions," Nanotechnology, vol. 29, no. 44, Article ID 445602, 2018.

[9] D. J. Norris, N. Yao, F. T. Charnock, and T. A. Kennedy, "High-quality manganese-doped ZnSe nanocrystals," Nano Letters, vol. 1, no. 1, pp. 3-7, 2001.

[10] N. Pradhan, D. Goorskey, J. Thessing, and X. Peng, "An alternative of CdSe nanocrystal emitters: pure and tunable impurity emissions in ZnSe nanocrystals," Journal of the American Chemical Society, vol. 127, no. 50, pp. 17586-17587, 2005.

[11] S. Coe, W.-K. Woo, M. Bawendi, and V. Bulović, "Electroluminescence from single monolayers of nanocrystals in molecular organic devices," Nature, vol. 420, no. 6917, pp. 800-803, 2002.

[12] B. Dong, L. Cao, G. Su, and W. Liu, "Facile synthesis of highly luminescent UV-blue emitting $\mathrm{ZnSe} / \mathrm{ZnS}$ core/shell quantum dots by a two-step method," Chemical Communications, vol. 46, no. 39, pp. 7331-7333, 2010.

[13] X. Xu, S. Li, J. Chen, S. Cai, Z. Long, and X. Fang, "Design principles and material engineering of $\mathrm{ZnS}$ for optoelectronic devices and catalysis," Advanced Materials, vol. 28, no. 36, pp. 1-3, 2018.

[14] I. Hernández-Calderón, "Optical properties and electronic structure of wide bandgap II-VI semiconductors," in II-VI Semiconductor Materials and Their Applications, C. T. Maria, Ed., vol. 12, pp. 113-170, Taylor \& Francis, New York, NY, USA, 2002.

[15] Q. Zhang, H. Li, Y. Ma, and T. Zhai, "ZnSe nanostructures: synthesis, properties and applications," Progress in Materials Science, vol. 83, pp. 472-535, 2016.

[16] X. Xu, L. Hu, N. Gao et al., "Controlled growth from ZnS nanoparticles to $\mathrm{ZnS}-\mathrm{CdS}$ nanoparticle hybrids with enhanced photoactivity," Advanced Functional Materials, vol. 25, no. 3, pp. 445-454, 2015.

[17] E. Soheyli, R. Sahraei, G. Nabiyouni, A. A. Hatamnia, A. Rostamzad, and S. Soheyli, "Aqueous-based synthesis of $\mathrm{Cd}$-free and highly emissive Fe-doped $\mathrm{ZnSe}(\mathrm{S}) / \mathrm{ZnSe}(\mathrm{S})$ core/ shell quantum dots with antibacterial activity," Journal of Colloid and Interface Science, vol. 529, pp. 520-530, 2018.

[18] F. Qiao, R. Kang, Q. Liang, Y. Cai, J. Bian, and X. Hou, "Tunability in the optical and electronic properties of $\mathrm{ZnSe}$ microspheres via $\mathrm{Ag}$ and $\mathrm{Mn}$ doping," ACS Omega, vol. 4, no. 7, pp. 12271-12277, 2019.

[19] D. Souri, M. Sarfehjou, and A. R. Khezripour, "The effect of ambient temperature on the optical properties and crystalline quality of $\mathrm{ZnSe}$ and $\mathrm{ZnSe}: \mathrm{Cu}$ NCs grown by rapid microwave irradiation," Journal of Materials Science: Materials in Electronics, vol. 29, no. 4, pp. 3411-3422, 2018.

[20] T. R. Kumar, P. Prabukanthan, G. Harichandran, J. Theerthagiri, S. Chandrasekaran, and J. Madhavan, "Optical, magnetic, and photoelectrochemical properties of electrochemically deposited $\mathrm{Eu}^{3+}$-doped $\mathrm{ZnSe}$ thin films," Ionics, vol. 23, pp. 2497-2507, 2017.

[21] M. Geszke, M. Murias, L. Balan et al., "Folic acid-conjugated core/shell $\mathrm{ZnS}: \mathrm{Mn} / \mathrm{ZnS}$ quantum dots as targeted probes for two photon fluorescence imaging of cancer cells," Acta Biomaterialia, vol. 7, no. 3, pp. 1327-1338, 2011.

[22] K. Pechstedt, T. Whittle, J. Baumberg, and T. Melvin, "Photoluminescence of colloidal CdSe/ZnS quantum dots: the critical effect of water molecules," The Journal of Physical Chemistry C, vol. 114, no. 28, pp. 12069-12077, 2011.

[23] D. V. Talapin, I. Mekis, S. Götzinger, A. Kornowski, O. Benson, and H. Weller, "CdSe/CdS/ZnS and CdSe/ZnSe/ ZnS Core-Shell-Shell nanocrystals," The Journal of Physical Chemistry B, vol. 108, no. 49, pp. 18826-18831, 2004.

[24] Isnaeni, K. H. Kim, D. L. Nguyen, H. Lim, P. T. Nga, and Y. H. Cho, "Shell layer dependence of photoblinking in CdSe/ ZnSe/ZnS quantum dots," Applied Physics Letters, vol. 98, Article ID 012109, 2011.

[25] Y.-S. Liu, Y. Sun, P. T. Vernier, C.-H. Liang, S. Y. C. Chong, and M. A. Gundersen, "pH-Sensitive photoluminescence of $\mathrm{CdSe} / \mathrm{ZnSe} / \mathrm{ZnS}$ quantum dots in human ovarian cancer cells," The Journal of Physical Chemistry C, vol. 111, no. 7, pp. 2872-2878, 2007.

[26] D. V. Talapin, A. L. Rogach, A. Kornowski, M. Haase, and $\mathrm{H}$. Weller, "Highly luminescent monodisperse CdSe and CdSe/ZnS nanocrystals synthesized in a hexadecylamine-trioctylphosphine oxide-trioctylphospine mixture," Nano Letters, vol. 1, no. 4, pp. 207-211, 2001.

[27] B. T. Luong, E. Hyeong, S. Yoon, J. Choi, and N. Kim, "Facile synthesis of UV-white light emission ZnSe/ZnS:Mn core/ (doped) shell nanocrystals in aqueous phase," RSC Advances, vol. 3, no. 45, pp. 23395-23401, 2013.

[28] G. Murugadoss, "Luminescence properties of co-doped ZnS: $\mathrm{Ni}, \mathrm{Mn}$ and $\mathrm{ZnS}: \mathrm{Cu}, \mathrm{Cd}$ nanoparticles," Journal of Luminescence, vol. 132, no. 8, pp. 2043-2048, 2012.

[29] M. Guzman, J. Dille, and S. Godet, "Synthesis and antibacterial activity of silver nanoparticles against gram-positive and gram," Nanomedicine: Nanotechnology, Biology, and Medicine, vol. 8, no. 1, pp. 37-45, 2011.

[30] Y. Y. Bacherikov, S. E. Lingua, A. G. Zhuk, N. A. Semenenko, and O. S. Krylova, "Luminescent properties of fine-dispersed $\mathrm{ZnS}: \mathrm{Cu}$ prepared using self-propagating high-temperature synthesis," Semiconductor Physics Quantum Electronics and Optoelectronics, vol. 17, no. 4, pp. 374-379, 2014. 
[31] J. Jones, "Infectious diseases," in Essential Human Disease for Dentists, pp. 177-194, Churchill Livingstone, London, UK, 2006.

[32] D. Jonas, M. Speck, F. D. Daschner, and H. Grundmann, "Rapid PCR-based identification of methicillin-resistant Staphylococcus aureus from screening swabs," Journal of Clinical Microbiology, vol. 40, no. 5, pp. 1821-1823, 2002.

[33] H. Al-Talib, C. Yean, A. Al-Khateeb et al., "A pentaplex PCR assay for the rapid detection of methicillin-resistant Staphylococcus aureus and Panton-Valentine Leucocidin," BMC Microbiology, vol. 9, no. 1, p. 113, 2009.

[34] R. Hagen, I. Seegmüller, J. Navai, I. Kappstein, N. Lehn, and T. Miethke, "Development of a real-time PCR assay for rapid identification of methicillin-resistant from clinical samples," International Journal of Medical Microbiology, vol. 295, no. 2, pp. 77-86, 2005.

[35] J. L. Holland, L. Louie, A. E. Simor, and M. Louie, "PCR Detection of Escherichia coli O157:H7 directly from stools: evaluation of commercial extraction methods for purifying fecal DNA," Journal of Clinical Microbiology, vol. 38, no. 11, pp. 4108-4113, 2000.

[36] M. A. Hahn, J. S. Tabb, and T. D. Krauss, "Detection of single bacterial pathogens with semiconductor quantum dots," Analytical Chemistry, vol. 77, no. 15, pp. 4861-4869, 2005.

[37] Ü. Dogan, E. Kasap, D. Cetin et al., "Rapid detection of bacteria based on homogenous immunoassay using chitosan modified quantum dots," Sensors and Actuators B: Chemical, vol. 233, pp. 369-378, 2016.

[38] L. Zheng, P. Qi, and D. Zhang, "Identification of bacteria by a fluorescence sensor array based on three kinds of receptors functionalized carbon dots," Sensors and Actuators B: Chemical, vol. 286, pp. 206-213, 2019.

[39] J. A. Kloepfer, R. E. Mielke, M. S. Wong, K. H. Nealson, G. Stucky, and J. L. Nadeau, "Quantum dots as strain- and metabolism-specific microbiological labels," Applied and Environmental Microbiology, vol. 69, no. 7, pp. 4205-4213, 2003.

[40] J. C. Bonilla, F. Bozkurt, S. Ansari, N. Sozer, and J. L. Kokini, "Applications of quantum dots in food science and biology," Trends in Food Science \& Technology, vol. 53, pp. 75-89, 2016.

[41] D. Bui, D. Pham, X. Mai et al., "Studying on synthesis of highly luminescent quantum dots based on zinc and their application for Escherichia coli O157:H7 and methicillin-resistant Staphylococcus aureus detection," Advances in Research, vol. 14, no. 4, pp. 1-8, 2018.

[42] F. Song and W. C. W. Chan, "Principles of conjugating quantum dots to proteins via carbodiimide chemistry," Nanotechnology, vol. 22, pp. 1-7, 2011.

[43] S. Pathak, M. C. Davidson, and G. A. Silva, "Characterization of the functional binding properties of antibody conjugated quantum dots," Nano Letters, vol. 7, no. 7, pp. 1839-1845, 2007.

[44] H. Qian, X. Qiu, L. Li, and J. Ren, "Microwave-assisted aqueous synthesis: a rapid approach to prepare highly luminescent $\mathrm{ZnSe}(\mathrm{S})$ alloyed quantum dots," The Journal of Physical Chemistry B, vol. 110, no. 18, pp. 9034-9040, 2006.

[45] A. B. Panda, S. Acharya, S. Efrima, and Y. Golan, "Synthesis, assembly, and optical properties of shape- and phase-controlled ZnSe nanostructures," Langmuir, vol. 23, no. 2, pp. 765-770, 2007.

[46] D. Zhu, X. Jiang, C. Zhao, X. Sun, J. Zhang, and J.-J. Zhu, "Green synthesis and potential application of low-toxic Mn: ZnSe/ZnS core/shell luminescent nanocrystals," Chemical Communications, vol. 46, no. 29, pp. 5226-5228, 2010.
[47] J. Zhang, Q. Chen, W. Zhang et al., "Microwave-assisted aqueous synthesis of transition metal ions doped $\mathrm{ZnSe} / \mathrm{ZnS}$ core/shell quantum dots with tunable white-light emission," Applied Surface Science, vol. 351, pp. 655-661, 2015.

[48] R. M. Krsmanović Whiffen, D. J. Jovanović, Ž. Antić et al., "Structural, optical and crystal field analyses of undoped and $\mathrm{Mn}^{2+}$-doped $\mathrm{ZnS}$ nanoparticles synthesized via reverse micelle route," Journal of Luminescence, vol. 146, pp. 133-140, 2014.

[49] H. Zhang, X. Gao, S. Liu, and X. Su, "One-pot synthesis of stable water soluble Mn:ZnSe/ZnS core/shell quantum dots," Journal of Nanoparticle Research, vol. 15, no. 6, p. 1749, 2013. 